\title{
State Policy of Environmental Convergence in Economy Transition to Sustainable Development
}

\author{
Sergey Zhironkin ${ }^{1}$, Olga Zhironkina ${ }^{2,}$, and Leszek Sobik $^{3}$ \\ ${ }^{1}$ Siberian Federal University, 660075 Lida Prushinskaya St. 2, Krasnoyarsk, Russia \\ ${ }^{2}$ Kemerovo State University, 650043, 6 Krasnaya St., Kemerovo, Russia \\ ${ }^{3}$ Polska Grupa Górnicza S.A., KWK ROW ruch Chwałowice, ul. Przewozowa 4, 44-206 Rybnik, \\ Poland
}

\begin{abstract}
Structural shifts caused by the expansion of "green" convergent technologies significantly enhance the ecological convergence of the economies in the countries in which they determine the exit to the trajectory of sustainable development. At the same time, in an economy where the commercialization and diffusion of green technologies is constrained by structural problems, the prerequisites for environmental divergence are formed, which can finally consolidate technological lag and a long-term trend of environmental degradation. The transition from environmental divergence to convergence should be carried out in a system of convergentoriented structural policy. It presents a three-level complex: targeted changes in the reproductive structure, the proportion of production factors (the first level); impact on the sectoral, technological, market-competitive, social structures of the economy (the second level), development of research, production and financial infrastructure for the commercialization and transfer of "green" technologies (the third level).
\end{abstract}

\section{Introduction}

Ecological convergence means such a change in the structural proportions of the national economy, which brings it closer to technologically ecological countries in environmental, reproduction (resource use, capital accumulation and consumption), technological and sectoral, social criteria, and, as a consequence, in proximity to the trajectory of sustainable development. Factors of environmental convergence include the growth of direct environmentally related investments, replacement of outdated equipment and technologies, increased commercialization and cross-industry transfer of innovations in green start-ups, a change in the structure of employment in favor of high-tech and research sectors, the formation of elite social groups focused on environmental protection, implementation environmental-stimulating structural policy.

Ecological divergence is antagonistically opposite to ecological convergence and represents an increase in the negative distance of the economy structure in terms of ecological, sectoral, innovation-technological, social proportions from developed countries.

\footnotetext{
* Corresponding author: o-zhironkina@mail.ru
} 
The prerequisites for environmental divergence are a reduction in direct investments in environmental protection measures and resource-saving technologies, outstripping growth in the export of natural resources, critical aging of fixed capital, which prevents the diffusion of resource-saving innovations and a drop in demand for "green" goods. Moreover, the collapse of environmentally oriented social groups and the implementation of structural policies in the interests of raw material elite are also in the list.

The change in the types of convergent-divergent processes in the field of environmental protection is the action of ecological convergence and divergence. Ecological convergence is the strengthening of the factors of structural shift, concentrating the effective diffusion of the latest achievements of scientific and technological progress, in combination with institutional, reproductive, market-competitive, social conditions. It is typical for countries in which the factor efficiency of capital and technology begins to return from the land factor in the form of natural rent (Singapore and South Korea, the countries of North America, Eastern and Western Europe).

On the contrary, structural divergence is associated with the separation into an independent trend of such negative processes as a reduction in green investment and the maintenance of a low accumulation rate, aging means of production. Increased investment in the extractive industry, a decline in non-resource exports, a critical drop in innovative activity, and an increase in the share of the poor are among other negative processes. They form radical differences between the country's economy and ecologically and technologically developed countries. With the beginning of a new long-term economic cycle, the unpreparedness of the reproduction system to ensure the "green" modernization of the economy will lead to the final lag behind the advanced countries and increase the dependence on outdated technologies and high resource consumption [1].

In the context of environmental divergence in the Russian economy, it is extremely important to increase its susceptibility to a new technological breakthrough, which should receive institutional, innovative, technological, and social support. A special role in the transition to sustainable development plays global trend of shifting to alternative power producing [2]. Without the use of internal sources of the convergent shift, the global diffusion of technologies will not be supported by the Russian economy, in which the technological lag will finally be fixed. The ecological-divergent path of development of the Russian economy is based on the growing technological lag behind the advanced countries, which can become irreversible in the context of the convergent-ecological modernization of the economies of advanced countries. Another sign of ecological divergence of Russian industry is lacking behind in the technologies of technogenic accidents prevention [3].

\section{Materials and Methods}

We identified the following as the reasons for the environmental divergence of the Russian economy:

1. State support for the development of science and technology is concentrated in narrow areas of research related to the extraction of raw materials and national defense (nuclear energy, oil and gas production, the defense complex, the space industry), without an emphasis on enhancing the international diffusion of green convergent technologies. In fact, the government programs for the industrial development have not increased the Russia's share in the world market for green products; on the contrary, its reduction is noted [4].

2. The negative ecological gap between Russia and the advanced countries is not only of reproductive-structural, but also of a market nature. It is intensified not only by technological restrictions on the supply of raw materials mined in Russia, but also by the accelerated development of world demand for innovative products. Thus, in 2014, the export of oil and its refined products from Russia exceeded the export of smartphones from China by $25 \%$ (\$ 
156 billion versus $\$ 125$ billion), then in 2017 it lagged behind by $14 \%$ ( $\$ 120$ billion dollars versus 139 billion dollars). In the Russian economy, the number of machine tools per capita is 34 times less than in Germany, 22 times less than in the United States, and 8.6 times less than in Switzerland [5]. All this narrows the opportunities for the commercialization of innovations in Russian industry, makes technological lagging behind the primary cause of environmental degradation.

3. The Russian defense-industrial complex is not making the required technological contribution to the change in the economy structure. In particular, in 2015, the export of smartphones and laptops from Vietnam exceeded the export of weapons from Russia by 2.4 times $-\$ 36$ billion versus a record for the Russian defense complex of $\$ 15$ billion [5].

4. Throughout the entire period of reforms in the reproduction system of the Russian economy, a low share of the research sector remains. In particular, R\&D expenditures of the Chinese company Huawei in 2016 exceeded $\$ 10$ billion, which is 9.7 times more than the total budget of the Russian Academy of Sciences (61.6 billion rubles). At the same time, the revenue (operating income) of Huawei in 2017 amounted to $\$ 81$ billion, which is $10 \%$ higher than the revenue of the Russian oil and gas monopoly company ROSNEFT $-\$ 72.4$ billion $[5]$.

Thus, the degradation nature of the ecological-divergent trend in the Russian economy is obvious, which, as the convergent technological mode of production expands in developed and a number of developing countries, can make Russia's ecological lagging behind irreversible.

Overcoming such a reproduction-conditioned ecological lag of the Russian economy is possible when initiating a structural shift of a convergent type. State support for the transfer of convergent technologies in the economy structure plays a key role in this.

The Russian economy has set goals for the development of convergent technologies in certain industries. Thus, the Forecast of the scientific and technological development of the Russian Federation until 2030 determines the most promising direction for the integration of technologies in nano-material construction, energy and energy conservation [6]. Convergent technologies in this area are associated with the creation and processing of crystalline and biocompatible nanomaterials, industrial production of membrane-catalytic systems - the basis of the future small and micro-"green" energy (instead of fossil energy sources burning $[7-8])$.

At the same time, despite the presence of a certain convergent technological groundwork in the Russian industry, the negative dynamics of environmental, innovation and social processes does not allow using the environmentally friendly technologies, even borrowing them from abroad, to overcome the environmental lag [9]. The "innovation-ecological maneuver" in the Russian economy, with its inherent de-industrialization and ecological divergence, requires a reorientation of industrial policy towards sustainable economic development.

That is, the transition to the initiation of environmental convergence in the course of the development of convergent technologies is possible only if they initiate their dissemination in the entire system of national reproduction - manufacturing the means of production and consumer goods, industrial, information, financial and social infrastructure [10]. This means the development of such state structural policy, which can provide to involve the main investors - large raw materials business, state corporations - in the process of creation, commercialization and transfer of "green" convergent technologies in all sectors of the economy.

\section{Results and Discussion}


The term "structural policy" in the works of prominent economists is often associated with the regulation of macroeconomic dynamics, rather than the entire complex of sustainable development - environmental, sectoral, technological, innovative, market, social proportions - everything that is collectively associated with a structural shift. Thus, the structuralist F. Perroux associated structural policy and the stimulation of economic growth in the course of selective influence on the processes of production and consumption [11].

We believe that the traditional understanding of structural policy as a purposeful regulation of meso-economic proportions does not meet the criteria of environmental convergence.

First, the structural policy does not cover changes in the very structure of technologies, which should be supported by positive changes in resource consumption and the expansion of green industries.

Second, the implementation of structural policy is based on the prerogative of the centralized allocation of investment resources by the state, with the diminution of the role of public-private partnerships and market self-regulation. Namely, the technology market today reflects breakthrough areas of sustainable development, creating conditions for the diffusion of "green" and lean production.

Third, ecological convergence is an objective process determined by the acceleration of scientific and technological progress, reduction in resource consumption and recycling, and the emergence of new network forms of interaction between investment entities, science and business. Therefore, ecological convergence reflects the objective processes in industry, due to scientific and technological progress. On the contrary, structural policy is largely a subjective process, depending on the priorities of state economic policy and the efforts of the authorities implementing it.

Fourth, structural policy is viewed as an instrument of short- and medium-term state regulation of the economy, associated with solving the most acute problems that threaten a crisis or dysfunction of individual elements of the structure of the national economy industries, sectors, and social groups. On the contrary, ecological convergence affects the entire system of social production and is ongoing.

Initiation of environmental convergence requires a structural policy that takes into account the entire multi-level complex of processes occurring in the economy under the influence of the transfer of convergent technologies in it, and contributes to the reduction of technological lag. We call such a structural policy convergent-oriented, and distinguish a number of levels in it.

The first (macroeconomic) level of convergent-oriented structural policy is associated with targeted changes in the reproduction structure, in the structure of the use of factors of production, including those associated with the transformation of property relations, the development of public-private partnerships. The convergence of technologies is creating new industries and markets in which investment cycles are significantly shorter than traditional industries, and whose companies lead in the world in terms of capitalization, and workers in terms of income. For example, the market capitalization of five American companies Alphabet (which includes Google), Apple, Amazon, Microsoft, SpaceX - which are actively investing in the interweaving of technologies in the IT sphere, energy, astronautics, and the automotive industry, exceeded 2.7 trillion dollars in 2017.

This, as well as the fact that an increase in the share of consumption of modern goods produced with the help of convergent technologies, the expansion of intellectual rent in technologically advanced countries makes investments in intellectual property and its reproduction most attractive. At the same time, traditional resource-intensive industries are fading into the background, accelerating the transition to sustainable development.

At the first level the key actors of a converged structural policy should include the following: 
- the highest level of executive power, including the President and the federal government, which set key macroeconomic benchmarks in such a way as to ensure the maximum attractiveness of sustainable, environmentally friendly development for all economic entities, as well as to develop scientific and industrial cooperation, intellectualization of labor. For this purpose, we see it expedient to use mainly indirect economic instruments, such as targeted programs for the development and implementation of "green" convergent technologies, subsidies to stimulate demand for "green" goods and services. To continue the list there are a shift in taxation from the profits of manufacturing and high-tech industries to natural rent, the use of state reserve funds to invest in the environmental modernization of industry;

- The Central Bank is the regulator of the monetary sphere, whose role is to create attractive financial conditions for investment in green convergent technologies. The central bank can exert a regulatory influence on the structure of investment and consumer demand and supply, using such instruments as the discount rate, foreign exchange interventions, emissions and yields of government obligations, bank reserve rates;

- the highest legislative and judicial authorities responsible for creating the institutional environment necessary for successful diffusion and cross-sectoral transfer of "green" technologies. Such an institutional environment should reduce the level of transaction costs of creation, transfer and widespread diffusion of "green" technologies.

At the second (meso-economic) level of a convergent-oriented structural policy, the regulation of market, sectoral, technological, and social proportions of the economy should be implemented. It is advisable to include the following as its subjects.

- Sectoral federal ministries and their constituent federal agencies and services (Federal Antimonopoly Service, Federal Agency for State Reserves). Their role is to implement laws and regulations in the field of environmental management, investment in green technological innovations. The tools of this circle of subjects of a convergent-oriented structural policy may include budget investments, government orders, subsidies, etc.

- State corporations and regional legislative and executive bodies. Their participation in ensuring environmental convergence is associated with the stimulation of cross-introduction of innovations by enterprises from adjacent industrial and innovation clusters, with the creation of databases of publicly available "green" technologies, financing of breakthrough resource-saving and recycling projects on the basis of a "full cycle venture of research, development and production". The instruments of the environmental convergence policy that these entities have at their disposal include regional laws and regulations governing the support of innovation clusters, corporate and state sub-federal orders, venture capital investments.

- Business associations and unions, the role of which is to put forward initiatives for legislative improvement of the conditions for the development of environmental convergence, in the course of coordinating the interests of high- and medium-tech business firms, their interaction with representatives of the scientific sector within the framework of technology platforms. In this interaction, mutual coordination of the interests of universities and research institutes, innovative firms and industrial enterprises, banks and investment companies, venture funds should be obtained, bringing them in line with the tasks of regulating the structural shift.

The third (meso- and microeconomic) level of convergent structural policy is to develop the necessary research, production and financial infrastructure for the transition to a green economy. Its role is to ensure the transfer of environmentally friendly and recycling innovations into production, which requires a radical turn of the interests of big business from extracting raw material rent to intellectual one, and to entering the world market with "green" products created in traditional basic sectors of the economy (renewable energy, chemistry of returnable polymers, robotics, etc.). 
We include government agencies, entrepreneurship support funds, venture capital funds, innovative companies and R\&D organizations, enterprises of the sixth and fifth sectors of technology (generating demand for resources and technologies created in the sixth) to the subjects that form the policy of environmental convergence at the third level. The regulators that these entities have at their disposal form a system of market self-regulation in high-tech industries (investments, inter-firm cooperation, corporate orders for $R \& D$, the formation of unions and alliances, business networks). Particularly noteworthy is the role of scientific schools of economics in initiating the third level of regulation of environmental convergence. The reason is in the fact that the related structural policy requires theoretical studies of its reproduction and institutional foundations, analysis of the relationship between the problems of market reforms, greening and convergent technological neo-industrialization of the economy, the formation of its "green" structures.

\section{Conclusion}

Thus, the entry of the Russian economy onto the trajectory of sustainable development is impossible without the initiation of ecological convergence in it. Its complexity requires the formation of a convergent-oriented structural policy, implemented at several levels of interaction between the state and business, using both direct and indirect instruments of state regulation of the economy. Institutional support of structural policy aimed at environmental convergence should include the federal list of priority "green" convergent technologies for public investment, subsidies, preferential taxation and insurance of convergent technological innovations. Along with that, it should consider the development and ratification of laws on state guarantees and insurance of investment in "green" technologies, subsidizing interest rates on long-term bank loans for companies implementing progressive resource conservation, on innovative outsourcing of green technologies.

\section{References}

1. A.A. Migranyan, E.V. Shavina, Contours of global transformations: politics, economics, law, 12(6), 220-245 (2019) DOI: 10.23932/2542-0240-2019-12-6-11

2. M. Beer, R. Rybár, M. Cehlár, S. Zhironkin, P. Sivák, Energies, 13(10), 2450 (2020)

3. M. Tutak, J. Brodny, D. Szurgacz, L. Sobik, S. Zhironkin, Energies, 13(18), 4891 (2020)

4. S.K. Demchenko, M.S. Zlotnikov, T.A. Melnikova, O.S. Demchenko, International Journal of Civil Engineering and Technology, 10(2), 1877-1884 (2019)

5. V.V. Guzyr', Economics and Innovation Management, 4, 4-19 (2019) DOI: 10.26730/2587-5574-2019-4-4-19

6. Forecast of scientific and technological development of the Russian Federation for the long term (up to 2030). Conceptual approaches, directions, forecast estimates and implementation conditions (Russian Academy of Sciences, Moscow, 2008)

7. S. Khouri, H. Pavolová, M. Cehlár, T. Bakalár, Metalurgija, 55(3), 500-502 (2016)

8. M. Cehlár, J. Janočko, Z. Šimková, T. Pavlik, E3S Web Conf. 15, 01019 (2017)

9. M. Cehlar, Economics and Innovation Management, 3, 24-31 (2019) DOI: 10.26730/2587-5574-2019-3-24-31

10. S.K. Demchenko, J.J. Suslova, A.S. Yamschikov, I.R. Ruyga, T.A. Melnikova, Journal of Applied Economic Sciences, 12(1), 194-205 (2017)

11. E.V. Shavina, 3, 4-13 (2019) DOI: 10.26730/2587-5574-2019-3-4-13 